\title{
Parhaat käytännöt maitotilan kehittämisen tukena
}

\author{
Sami Ovaska ${ }^{1)}$, Timo Sipiläinen ${ }^{2)}$, Matti Ryhänen ${ }^{3)}$ \\ ${ }^{1)}$ MTT Taloustutkimus, Latokartanonkaari 9,00790 Helsinki, sami.ovaska@mtt.fi \\ ${ }^{2)}$ Helsingin yliopisto ja MTT Taloustutkimus, Taloustieteen laitos, PL 27, 00014 Helsingin yliopisto, \\ timo.sipilainen@helsinki.fi \\ ${ }^{3)}$ Seinäjoen ammattikorkeakoulu, Maa- ja metsätalouden yksikkö, Ilmajoentie 525, 60800 Ilmajoki, \\ matti.ryhanen@seamk.fi
}

\section{Tiivistelmä}

Tuottavuuden jatkuva parantaminen on keskeinen keino, jolla maidontuottaja voi ylläpitää tai parantaa tuotannon kannattavuutta. Usein tuottavuuden parantaminen ja tilakoon kasvu kytkeytyvät toisiinsa, koska uuden tekniikan hyödyntäminen on sidoksissa tiettyyn yrityskokoon.

Maitotilojen tuottavuudessa ja siten suhteellisessa teknisessä tehokkuudessa on eroja. Osa tehokkuuseroista aiheutuu erilaisista tuotanto-oloista ja tuotantotekniikoista, joiden muuttaminen etenkin lyhyellä aikavälillä voi olla lähes mahdotonta. Osa eroista johtuu puolestaan toimintatavoista ja tuotantoprosessien hallinnasta eli siitä, miten hyvin tuotantovälineistö kyetään käyttämään hyväksi. Näiltä osin toimintaa voidaan parantaa myös lyhyellä tähtäimellä. Tuotantoprosessien hallinta on muuttunut aiempaa haasteellisemmaksi tilakoon kasvaessa ja tuotantotekniikan monimutkaistuessa.

Maitotilan toiminnassa voidaan pyrkiä tilatason ideaalimallien sekä vaihtoehtoisten ratkaisujen määrittämiseen. Tilan toimintaa voidaan mallintaa ja optimoida sitä asetettujen rajoitteiden puitteissa. Tilannetta voidaan arvioida myös tilan historian ja kehityksen kautta ja arvioida eri toimien vaikutusta. Olennaista on kuitenkin löytää relevantteja vertailukohteita, vertailutiloja tai vertailuprosesseja. Tällöin keskeiseksi kysymykseksi nousee, miten vertailukohteet valitaan. Koska kunkin tilan näkökulmasta parhaan mahdollisen vertailukohdan määrittäminen on mahdotonta, voidaan tukeutua päätöksentekijän omiin preferensseihin, ja soveltaa vuorovaikutteisuutta vertailun laadinnassa.

Tässä tutkimuksessa tunnistetaan DEA- ja FDH -pohjaisten tehokkuusanalyysien avulla suhteellisesti parhaiten onnistuneet maitotilat, jotta niiden soveltamista parhaista käytännöistä voidaan oppia. Tehokkuusanalyysia sovelletaan Etelä-Pohjanmaalta vuonna 2010 kerättyyn yli 200 maitotilan tutkimusaineistoon. Yli 20 lehmän lypsykarjoista koostuva aineisto kattaa tilojen työnkäyttöä ja konepääomaa selvittäneen haastatteluaineiston, ProAgrian tuotanto-olosuhteita ja -tekniikkaa kuvaavan "tonkka-aineiston" sekä tilojen tulo- ja menoaineiston usean vuoden ajalta.

Taustamuuttujien avulla vertailujoukkoa voidaan rajata ja kohdentaa vertailua tarkoituksenmukaisesti. Omaa tilaa halutaan yleensä verrata samankokoisiin ja sitä suurempiin tai toista teknologiaa käyttäviin tiloihin. Taustamuuttujia käytetään myös tunnistettaessa tekijöitä, jotka ovat tilojen tehokkuuserojen taustalla. Tavoitteena on yksittäisen maitotilan toiminnan kehittäminen.

Avainsanat: maitotilat, kustannustehokkuus, DEA, FDH, benchmarking 


\section{Johdanto}

Maidontuottaja voi pyrkiä parantamaan tuotannon kannattavuutta usein eri tavoin. Näistä tuottavuuden parantaminen on keskeinen keino. Kasvatettaessa tilakokoa voidaan usein ottaa käyttöön uutta tuotantotekniikkaa, jolla voidaan pyrkiä esimerkiksi tuottamaan maitolitra aiempaa pienemmällä työmäärällä. Tällöin tavoitteeksi on asetettu työn tuottavuuden parantaminen. Tämä ei kuitenkaan automaattisesti tarkoita tilan kokonaistuottavuuden parantumista, sillä investointien myötä pääoman tuottavuus saattaa vastaavasti laskea.

Tuottavuus ja suhteellinen tekninen tehokkuus saattavat vaihdella merkittävästi tilojen välillä. Erojen taustalla on usein syitä, joihin maidontuottajan on vaikea vaikuttaa. Näitä voivat olla esimerkiksi tilan tuotanto-olosuhteisiin liittyvät peltolohkojen koko ja sijainti. Samoin navetassa käytettävää tuotantotekniikkaa saattaa olla vaikea muuttaa lyhyellä tähtäimellä. Toisaalta tilojen välillä voi olla suuria eroja tuottavuudessa ja suhteellisessa teknisessä tehokkuudessa, vaikka tuotanto-olot ja tuotantotekniikat olisivatkin samankaltaisia. Tällöin kyseessä voivat olla erot tuotantoprosessien hallinnassa ja onnistumisessa tuotantovälineistön hyväksikäytössä.

Maitotilan toimintaa on mahdollista kehittää ottamalla oppia parhaista sovelletuista käytännöistä (benchmarking). Tällöin keskeinen kysymys on, miten relevantit vertailutilat tai -prosessit valitaan. $\mathrm{Ne}$ voidaan valita vuorovaikutteisesti maidontuottajan omien mieltymysten perusteella, sillä yksikäsitteisen parhaan mahdollisen vertailukohdan määrittäminen on mahdotonta tilojen välisten erojen vuoksi. Maidontuottaja voi rajata vertailujoukkoa haluamallaan tavalla, kuten vertailla omaa tilaansa parhaiten onnistuneisiin samankokoisiin ja sitä suurempiin tai toista tuotantoteknologiaa käyttäviin tiloihin. Aineiston taustamuuttujien avulla voidaan myös tunnistaa tekijöitä, jotka vaikuttavat tilojen tehokkuuserojen taustalla.

\section{Aineisto ja menetelmät}

Tämän tutkimuksen otos muodostettiin poimimalla maatilarekisteristä aluksi kaikki Etelä-Pohjanmaan ELY -keskuksen alueen yli 20 lehmän maitotilat. Nämä järjestettiin koon mukaan suuruusjärjestykseen. Tiloista valittiin otokseen joka toinen (1. tila, 3. tila, 5. tila jne.). Tällä tavoin tehtynä tilaotokseen saatiin 320 tilaa, jotka pysyivät samoina koko tutkimusjakson ajan. Tutkimusaineistoa hankittiin useista eri lähteistä. Lopullinen tutkimusaineisto sisälsi tiloilta jo olemassa olevat keskeiset rekisteritiedot vuosilta 2006-2009, joita täydennettiin kesän 2010 aikana tehdyillä tilahaastatteluilla.

Tilastokeskuksesta saatiin tutkimuksen käyttöön maatilayritysten veronalaiset tulot, menot, varat ja velat yhteensä 313 otostilalta. Maaseutuelinkeinohallinnon tietojärjestelmän (Maa- ja metsätalousministeriön tietopalvelukeskus Tike ja Maaseutuvirasto Mavi) rekistereistä saatiin tilojen maito- ja eläinmäärät, peltoalat (oma ja vuokra), eri kasvilajien pinta-alat sekä viljelijän sukupuoli ja ikä.

Haastattelutiloja ei valikoitu etukäteen. Valtaosa haastattelutiloista kuului ProAgria EteläPohjanmaan asiakastiloihin tuotostarkkailun kautta (201 tilaa), mutta joukossa oli myös 24 tuotostarkkailuun kuulumatonta tilaa. Tilaotoksen 320 tilasta 225 tilaa suostui ProAgria Etelä-Pohjanmaan tekemään tilahaastatteluun ja 95 tilaa kieltäytyi. Siten haastatelluiksi saatiin $70 \%$ otostiloista.

Tilahaastatteluissa hankittiin sellaisia tietoja, joita ei ollut saatavissa muista lähteistä. Näistä tärkeimmät olivat työmäärät sekä koneet ja kalusto. Tilojen työmäärien keräämisessä hyödynnettiin Työtehoseuran (TTS tutkimus) kehittämää maatilan työmäärän suunnittelu- ja hallintaohjelmaa (TTSManager). Tutkimustiloilla tehtiin vuodessa keskimäärin 5298 tuntia maataloustyötä, josta 70 \% käytettiin kotieläintöihin. Koneiden ja kaluston arvot määritettiin samoin perustein kuin MTT Taloustutkimuksen kannattavuuskirjanpitotiloilla. Koneille ja kalustolle määritettiin jälleenhankinta-arvot, joille tehtiin ikää vastaavat vuotuiset menojäännöspoistot.

ProAgria Maatalouden Laskentakeskuksesta saatiin tuotostarkkailuun kuuluvilta haastattelutiloilta tutkimuksessa tarvittavat karjakohtaiset tiedot (mm. maidon laatutiedot, poistoprosentti, poikimaväli) sekä tilahaastattelujen yhteydessä päivitettyjä tietoja navetasta ja siellä käytettävästä teknologiasta ("tonkka-aineisto"). Tilastokeskuksessa yhdistettiin edellä kuvatut aineistot yhdeksi aineistoksi, josta muodostui lopullinen tutkimusaineisto (ei sisällä tilatunnistetietoja).

Tässä tutkimuksessa käytettiin DEA (Data Envelopment Analysis) -malleja tunnistamaan suhteellisesti parhaiten onnistuneet tilat. Kyseisiä malleja voidaan käyttää esimerkiksi tilojen keskinäisten suhteellisten tehokkuuksien mittaamiseen (Färe ym. 1994; Coelli ym. 1998). Mallien etuja ovat mahdollisuus käsitellä helposti useita panoksia ja tuotoksia samanaikaisesti sekä vähäiset tarvittavat oletukset tuotantoteknologiasta. Haittapuolena on perusmuodossa stokastisuuden puuttuminen, jolloin 
kaikkein suotuisimmat tapaukset määrittävät niin sanotun tehokkaan pinnan. Tämän vuoksi mahdollisten poikkeavien havaintojen tunnistaminen on tärkeää. Poikkeavien havaintojen kohdalla keskeiseksi ongelmaksi saattaa nousta se, onko kyseessä todellinen saavutettavissa oleva tehokkaasti toimiva parhaan käytännön tila vai johtuuko hyvä suorituskyky esimerkiksi mittausvirheestä tai sattumasta.

Ensimmäisessä vaiheessa tutkittiin 214 haastattelutilan suorituskykyä tehokkuusvertailulla. DEA-perusteiset tehokkuusanalyysit tehtiin OnFront-ohjelmistolla (EMQ 2000). Mallissa käytettiin yhtä tuotosta, joka oli maatalousverotuksen mukaiset maataloustuotteiden myyntitulot vuodelta 2009. Tuotantopanoksia olivat työ (h/v), pelto (ha), koneiden ja kaluston arvo (€), ostomenot (alv $22 \%$ ), alennetun verokannan mukaiset ostomenot (alv 8 tai $17 \%$ ).

Benchmarkkauksessa on olennaista mahdollisuus valita ne vertailukohteet, joihin oman tilan suoriutumista verrataan. Tähän tarkoitukseen voidaan käyttää DEA-menetelmään perustuvaa vuorovaikutteista Analyst-benchmarkkausohjelmaa, jossa päätöksentekijä toimii vuorovaikutteisesti benchmarkkausohjelman kanssa etsien omalta kannaltaan mielekkäimpiä vertailutiloja (Bogetoft ja Nielsen 2005).

Kuvassa 1 on esitetty vuorovaikutteisuuden periaate ja käyttäjän ohjaama benchmarkkien etsintä Analyst-ohjelmassa. Vertailuyksiköt voidaan muodostaa haluttaessa tehokkaiden tilojen sijaan (kuva 1, ylempi käyrä) halutusta alemman tehokkuuden osajoukosta (kuva 1, alempi käyrä). Halutut vertailuyksiköt voidaan muodostaa myös muiden luokittelijoiden, kuten tilakoon tai sijainnin, perusteella (Bogetoft ja Nielsen 2005, 196-199). Vertailutila voidaan myös muodostaa FDH (Free Disposal Hull) -mallilla, jossa tuotantomahdollisuuksien joukko on muodostettu ilman konveksisuusoletusta. Tällöin tehokas pinta ja vertailutilat voidaan koostaa yksittäisistä tiloista. Useimmiten DEA:n vertailutilat muodostetaan painokertoimilla useasta eri tilasta (konveksi kombinaatio) (Bramsen ja Nielsen 2004, 113, Cooper ym. 2000, 105). Kuvassa 2 on esitetty Analyst-ohjelman käyttöliittymä.

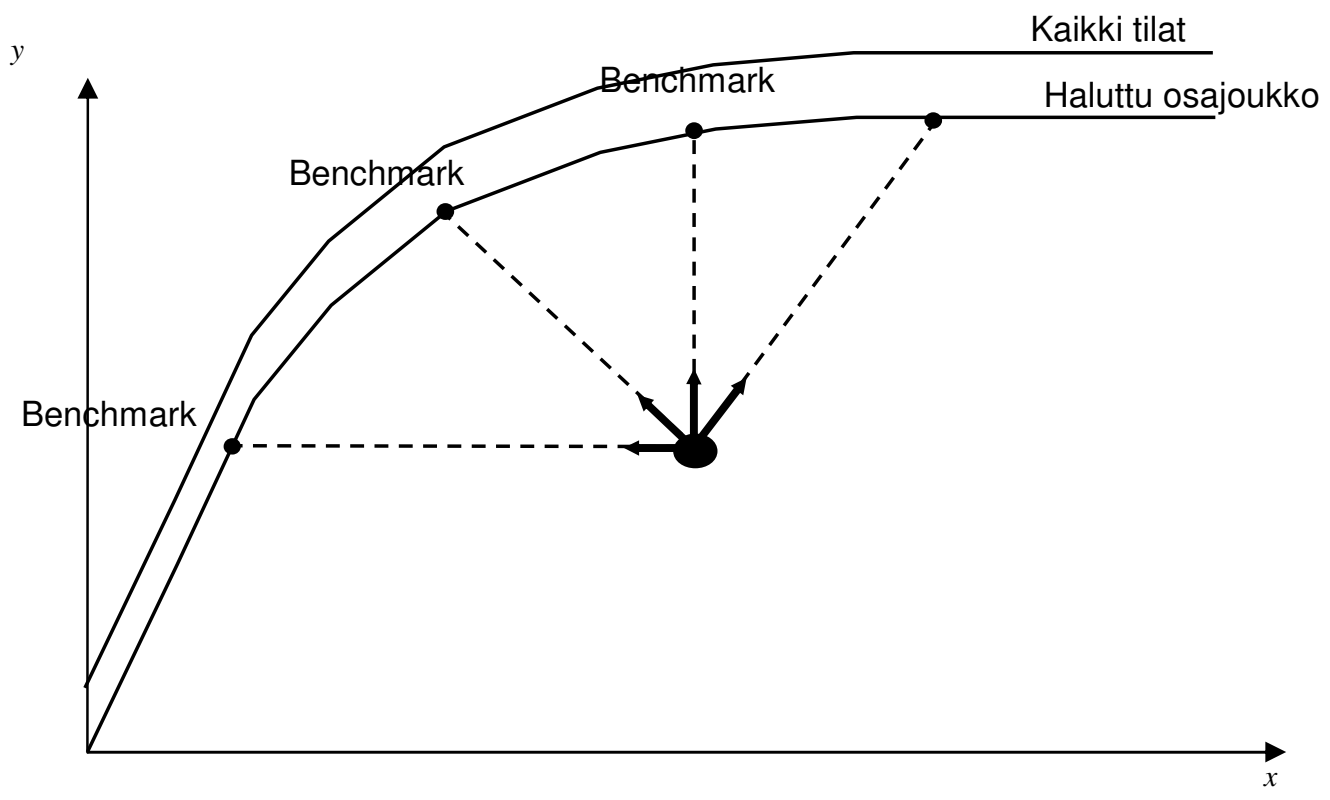

Kuva 1. Käyttäjän ohjaama benchmarkkien etsintä. 


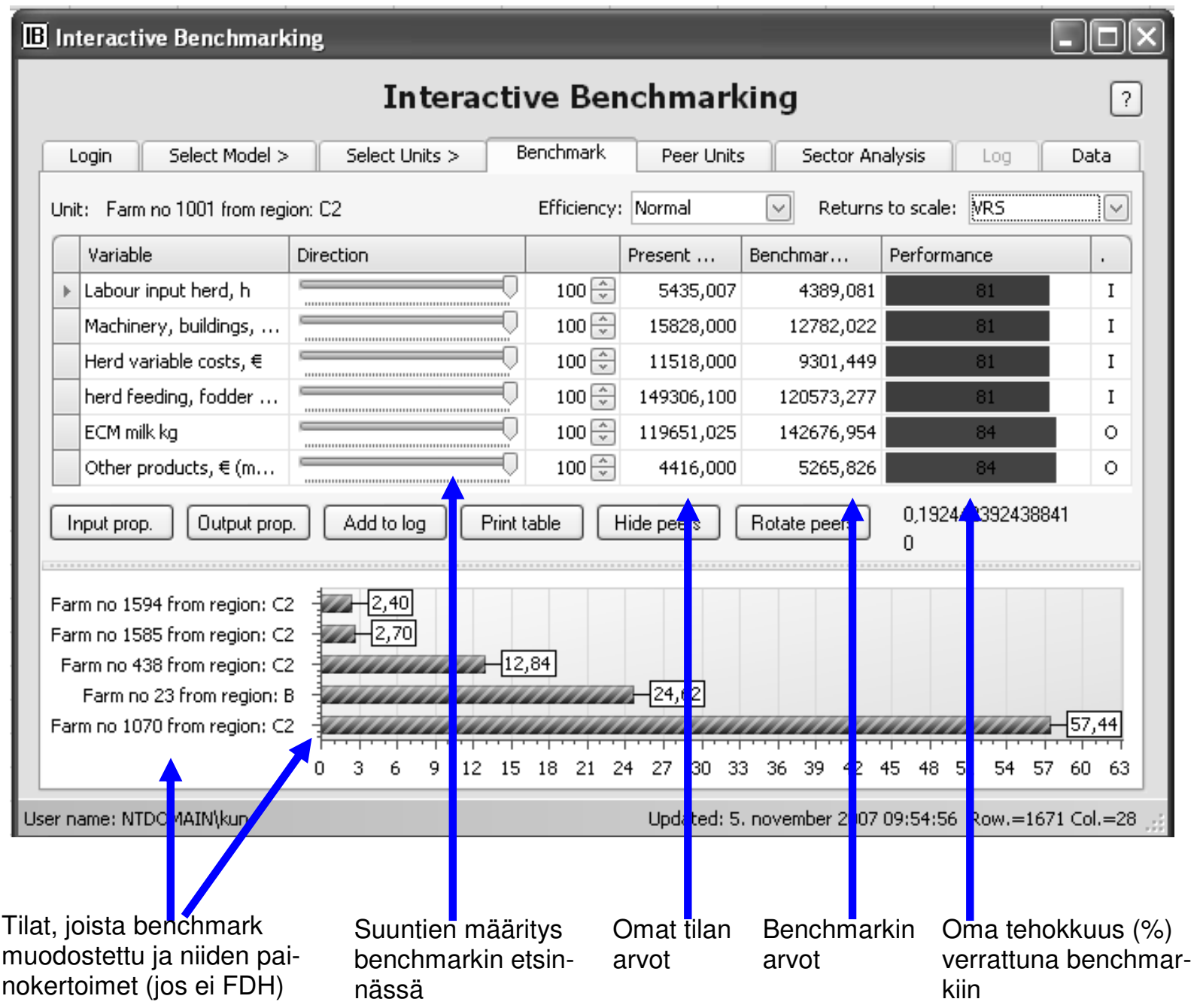

Kuva 2. Analyst -ohjelman käyttöliittymä.

\section{Tulokset ja tulosten tarkastelu}

Taulukossa 1 esitetään Etelä-Pohjanmaalla olevien yli 20 lypsylehmän tutkimustilojen tietoja vuosilta 2006 - 2009. Tutkimustilojen koko on kasvanut tutkimusajanjaksolla, mikä näkyy lehmä- ja maitomäärien sekä peltoalan kasvuna. Lehmämäärä kasvoi 14 prosenttia, maitotuotos 16 prosenttia, mutta keskituotos nousi vain 1,2 prosenttia neljässä vuodessa. Maidontuotanto kasvoi vuosina 2006 - 2009 haastattelutiloilla (214 tilaa) 19 prosenttia, mutta haastatteluun osallistumattomilla tiloilla vain 9 prosenttia. Tuotannon rakenteen muutoksesta kertoo se, että 20 - 30 lehmän maitotilat ovat vähentyneet tutkimusjaksolla 41 tilalla (taulukko 2). Tilojen lukumäärä on vastaavasti kasvanut tätä suuremmissa karjakokoluokissa.

Taulukko 1. Tutkimustilojen tuotanto ja sen kehitys vuosina 2006 - 2009.

\begin{tabular}{|c|c|c|c|c|c|c|}
\hline $\begin{array}{l}\mathrm{N}=311 \\
\text { Vuosi }\end{array}$ & $\begin{array}{l}\text { Lehmiä } \\
\text { kpl yht. }\end{array}$ & $\begin{array}{l}\text { Maitotuotos } \\
1 \text { yht. }\end{array}$ & $\begin{array}{l}\text { Keskilehmäluku } \\
\text { kpl/tila }\end{array}$ & $\begin{array}{l}\text { Maitotuotos } \\
\text { 1/tila }\end{array}$ & $\begin{array}{l}\text { Keskituotos } \\
\text { 1/lehmä }\end{array}$ & $\begin{array}{l}\text { Pelto yht. } \\
\text { ha }\end{array}$ \\
\hline 2006 & 10531 & 80159081 & 34 & 257746 & 7611 & 62 \\
\hline 2007 & 10901 & 83997718 & 35 & 270089 & 7705 & 64 \\
\hline 2008 & 11468 & 87868070 & 37 & 282534 & 7662 & 67 \\
\hline 2009 & 12033 & 92714915 & 39 & 298119 & 7705 & 69 \\
\hline 06-09 muutos, $\%$ & $14 \%$ & $16 \%$ & $14 \%$ & $16 \%$ & $1,2 \%$ & $12 \%$ \\
\hline
\end{tabular}


Taulukko 2. Tilamäärien muutokset karjakokoluokittain tutkimustiloilla vuosina 2006 ja 2009.

\begin{tabular}{|c|c|c|c|c|c|c|}
\hline $\mathrm{N}=311$ & Karjak & nää & & & & \\
\hline Vuosi & $20-30$ & $30-45$ & $45-60$ & $60-75$ & $75-90$ & yli 90 \\
\hline 2006 & 168 & 88 & 37 & 11 & 4 & 3 \\
\hline 2009 & 127 & 103 & 44 & 24 & 4 & 9 \\
\hline 06-09 muutos & -41 & +15 & +7 & +13 & 0 & +6 \\
\hline
\end{tabular}

Taulukossa 3 esitetään tutkimustilojen maatalousverotustietojen keskiarvotietoja. Vuosina 2006 - 2009 maataloustuotteiden myyntitulot ovat kasvaneet $33 \%$. Tulojen kasvusta pääosa selittyy maidon myyntitulojen kasvulla. Menot ovat vastaavasti kasvaneet $23 \%$ (ennen korjauseriä ja korkoja). Tärkeimmistä menoeristä ostomenot (alv $22 \%$ ) ovat kasvaneet $22 \%$. Tätä alemman verokannan (8 tai $17 \%$ ) ja pääosin rehumenoja sisältävät ostomenot ovat kasvaneet $23 \%$. Myös maatalouden verotuksen mukainen tulos on noussut $21 \%$.

Taulukko 3. Tutkimustilojen maatalouden veronalaiset tulot, menot, varat ja velat vuosina 2006 - 2009.

\begin{tabular}{lrrrr} 
N=311 & & & & \\
Verotustiedot (tilojen keskiarvot), euroa/tila & 2006 & 2007 & 2008 & 2009 \\
\hline Maataloustuotteiden myyntitulo & 111136 & 126018 & 153850 & 148366 \\
Tuet & 76920 & 71140 & 76925 & 80224 \\
Ostomenot, alv 22\% & 57311 & 59958 & 71374 & 70057 \\
Ostomenot, alv 8 tai 17\% & 27022 & 29908 & 34786 & 33241 \\
Poistot & 22798 & 24544 & 28628 & 28906 \\
Menot yhteensä & 132803 & 141167 & 164169 & 163148 \\
& & & & \\
Tulos maataloudesta & 51102 & 50970 & 61313 & 61755 \\
& & & & \\
Maatalouden varat & 229479 & 254181 & 261643 & 257147 \\
Maatalouden velat & 161085 & 181376 & 187054 & 194804
\end{tabular}

Taulukossa 4 esitetään tutkimustilojen kustannustehokkuudet (Oi), tekniset tehokkuudet (Fi) ja allokatiiviset tehokkuudet (Ai) kokoluokittain ja vuoden 2009 tilatiedoin. Tehokkuusluvuissa C tarkoittaa vakioskaalatuotto-oletusta ja $\mathrm{V}$ muuttuvien skaalatuottojen oletusta laskennassa sekä $\mathrm{S}$ panosten vapaata tuhlattavuusoletusta. Alle 200000 litraa vuodessa tuottavilla maitotiloilla tekninen tehokkuus Fi(C,S) on keskimäärin 0,78 ja kustannustehokkuus Oi(C,S) keskimäärin 0,49 . Siten pienimmän kokoluokan tilat voisivat keskimäärin tuottaa saman verran maitoa 22 prosenttiyksikköä alemmalla panosmäärällä (samansuhteinen panosvähennys) ja 51 prosenttiyksikköä alemmin kustannuksin (yksikkökustannukset minimoiva panosvähennys), jos tilat voisivat toimia tehokkaan vertailutilan tavoin.

Taulukko 4. Tutkimustilojen kustannustehokkuudet (Oi), tekniset tehokkuudet (Fi) ja allokatiiviset tehokkuudet (Ai) kokoluokittain.

\begin{tabular}{|c|c|c|c|c|c|c|c|c|}
\hline Maitoa, I/v (2009) & $\begin{array}{c}\text { Tiloja } \\
\text { kpl }\end{array}$ & $\begin{array}{l}\text { Lehmiä } \\
\text { keskim. }\end{array}$ & $\mathrm{Oi}(\mathrm{C}, \mathrm{S})$ & $\mathrm{Oi}(\mathrm{V}, \mathrm{S})$ & $\mathrm{Fi}(\mathrm{C}, \mathrm{S})$ & $\mathrm{Fi}(\mathrm{V}, \mathrm{S})$ & $\mathrm{Ai}(\mathrm{C}, \mathrm{S})$ & $\mathrm{Ai}(\mathrm{V}, \mathrm{S})$ \\
\hline Alle 200000 & 49 & 24 & 0,49 & 0,64 & 0,78 & 0,89 & 0,63 & 0,72 \\
\hline $200000-400000$ & 113 & 36 & 0,59 & 0,65 & 0,82 & 0,87 & 0,72 & 0,74 \\
\hline $400000-600000$ & 26 & 60 & 0,64 & 0,66 & 0,87 & 0,88 & 0,74 & 0,74 \\
\hline yli 600000 & 12 & 91 & 0,66 & 0,66 & 0,89 & 0,91 & 0,74 & 0,72 \\
\hline
\end{tabular}

Muuttuvien skaalatuottojen oletuksella tiloja verrataan saman kokoluokan tiloihin. Tällöin pienimmässä kokoluokassa voitaisiin keskimäärin tuottaa saman verran maitoa 11 prosenttiyksikköä alemmalla panosmäärällä (samansuhteinen panosvähennys $\mathrm{Fi}(\mathrm{V}, \mathrm{S})$ ) ja 36 prosenttiyksikköä alemmin kustannuk- 
sin (yksikkökustannukset minimoiva panosvähennys $\mathrm{Oi}(\mathrm{V}, \mathrm{S})$ ), jos tilat voisivat toimia tehokkaan, saman kokoluokan vertailutilan tavoin.

\section{Johtopäätökset}

Tämän tutkimuksen 320 Etelä-Pohjanmaan maitotilaa kattava tila-aineisto koottiin useasta eri lähteestä hyödyntämällä olemassa olevia rekisteritietoja, joita täydennettiin tilahaastatteluin (225 tilaa). Aineistosta rajattiin pois alle 20 lehmän tilat, sillä tarkastelu haluttiin kohdentaa tuotantoaan kehittäviin tiloihin. Tutkimustiloilla tuotantoa on kasvatettu merkittävästi vuosina 2006 - 2009. Maitomäärä on kasvanut keskimäärin $16 \%$, eläinmäärä $14 \%$ ja peltoala $12 \%$. Tulosten perusteella tuotantoa on kasvatettu selvästi enemmän haastattelutiloilla (19\%) verrattuna haastatteluun osallistumattomiin tiloihin (9 \%). Haastattelutiloista lähes kaikki kuuluivat ProAgria Etelä-Pohjanmaan tuotostarkkailun piiriin, mutta ei-haastattelutilat eivät siihen kuuluneet. Tutkimustilojen karjakoot olivat myös kasvaneet merkittävästi.

Tuotannon kasvattaminen näkyi osin myös tilojen maatalousverotustiedoissa. Tilojen myyntitulot olivat nousseet tutkimusaikana keskimäärin $33 \%$, menot $23 \%$ ja verotuksen mukainen tulos $21 \%$. Kustannustehokkuuden osatekijöistä panosten käytön tehokkuutta mittaava tekninen tehokkuus nousi vakioskaalatuotto-oletuksella tilakoon kasvaessa aina suurimpaan kokoluokkaan saakka. Eri panosten hintasuhteisiin perustuvaa ja niiden oikeaa käyttöä mittaava allokatiivinen tehokkuus ei sen sijaan noussut yli 400000 litran vuosituotoksen tiloilla. Teknisen ja allokatiivisen tehokkuuden tulona saatava kustannustehokkuus nousi tilakokoluokan kasvaessa vain vakioskaalatuotto-oletuksella.

Benchmarkkauksella voidaan verrata omaa maitotilaa tehokkaasti toimiviin parhaan käytännön tiloihin. Vuorovaikutteista benchmarkkausta voidaan tehdä Analyst-ohjelmalla, jossa maidontuottaja määrittää omien mieltymystensä perusteella haluamansa vertailutilan/-tilat. Näin toimien maidontuottaja voi hakea keinoja parantaa taloudellista tulosta ja kannattavuutta.

\section{Kirjallisuus}

Bogetoft, P. \& Nielsen, K. 2005. Internet Based Benchmarking. Journal of Group Decisions and Negotiations 14: $195-215$.

Bramsen, J.M. \& Nielsen, K. 2004. Interaktiv benchmarking. Med eksempler fra landbruget.

Fødevareøkonomisk Institut. Rapport nr. 172. København. 117 s.

Coelli, T., D. Prasado Rao \& G.E. Battese 1998. An Introduction to Productivity and Efficiency Analysis, Kluwer Academic Publishers.

Cooper, W., Seiford, L.M. \& Tone, K. 2000. Data Envelopment Analysis: A Comprehensive Text with Models, Applications, References, and DEA-Solver Software. Boston: Kluwer. 318 s.

EMQ 2000. On Front 2.0. The Professional Tool For Efficiency and Productivity Measurement. Economic Measurement and Quality in Lund Corporation.

Färe, R., S. Grosskopf \& C.A.K. Lovell. 1994. Production Frontiers. 